\title{
Grape cells
}

H. Baum

Institut für Laboratoriumsmedizin, Mikrobiologie und Blutdepot, Regionale Kliniken Holding RKH GmbH, Ludwigsburg, Deutschland

Synonym(e) Mottzelle; Morulazelle; Maulbeerzelle

\section{Englischer Begriff grape cell}

Definition Plasmazelle mit vielen intrazytoplasmatischen Vesikeln, die mit Immunglobulin gefüllten Granula ( $\triangleright$ Russell-Körperchen) entsprechen.

Beschreibung Die „Grape cell“ ist eine $>$ Plasmazelle. Sie zeigt ein dunkelbasophiles Zytoplasma und einen chromatindichten exzentrisch gelegenen Kern. Sie kann von der normalen Plasmazelle durch das Vorhandensein großer intrazytoplasmatischer, sich homogen anfärbender Granula ( $\vee$ Russell-Körperchen) unterschieden werden.

In der Abbildung ist eine „Grape cell“" mit intrazytoplasmatischen Vesikeln (Russell-Körperchen) zu sehen $(1000 \times$, May-Grünwald-Giemsa-Färbung):

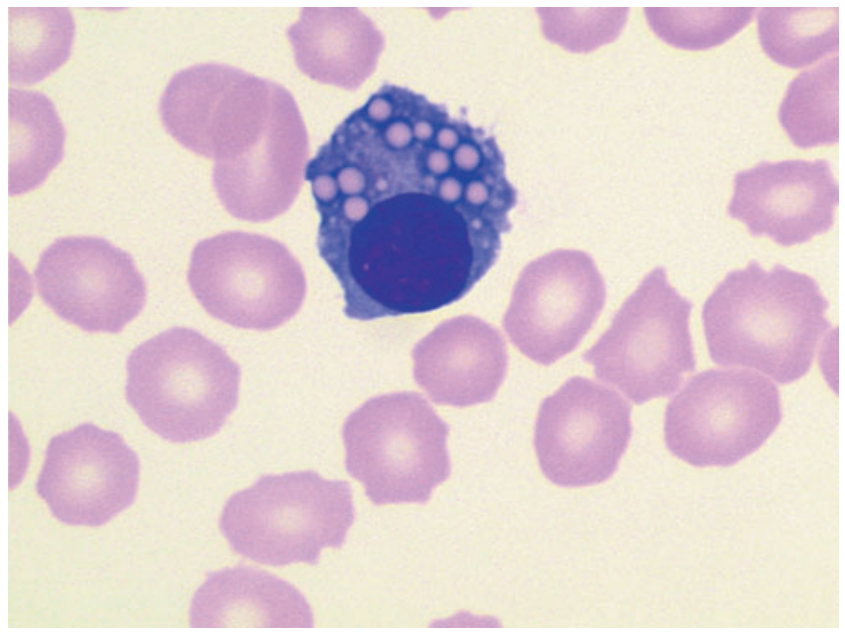

In diesen Granula kann Immunglobulin nachgewiesen werden. Diese „Grape cells“ können u. a. beim multiplen Myelom gefunden werden, haben jedoch keine besondere diagnostische Bedeutung.

\section{Literatur}

Löffler H, Rastetter J (1999) Atlas der Hämatologie, 5. Aufl. SpringerVerlag, Berlin/Heidelberg/New York, S 350 